\title{
「トルシア形高力ボルトを用いた摩擦接合により一体化した 鋼木複合断面軸力材の曲げ特性」に対する討論
}

（遠藤俊貴，高木次郎，荒木慶一，見波 進，十時 哲著 日本建築学会構造系論文集， 第76巻，第661号，591-598，2011年 3 月号掲載)

\section{DISCUSSION ON RESEARCH ACTIVITY PUBLISHED AS “BENDING PROPERTIES OF STEEL-TIMBER COMPOSITE AXIAL MEMBERS FORMED WITH FRICTION-TYPE CONNECTIONS USING TORSHEAR-TYPE HIGH-STRENGTH BOLTS"}

(Toshiki ENDO, Jiro TAKAGI, Yoshikazu ARAKI, Susumu MINAMI and Tetsu TOTOKI, J. Struct. Constr. Eng., AIJ, Vol. 76, No. 661, 591-598, Mar., 2011)

\section{桑 村 仁* \\ Hitoshi KUWAMURA}

\begin{abstract}
Experimental and analytical achievements on the shear stiffness and strength of steel-to-timber connections tightened by high-strength bolts in the above paper are discussed about the following items. 1) The opinion that the shear resistance between steel and timber is attributed to the friction seems illogical, because the shear stiffness is not influenced by the tension reserved in the bolt. 2) The proposed formula for calculating the shear strength seems improper, because the model does not reflect the real nature of the shear resistance. 3) The data of connection, beam, and others may not be consistent, because the water content of the tested timber is not controlled in a limited range.
\end{abstract}

Keywords : Steel, Timber, Composite member, High-strength bolt, Friction, Bearing 鋼材，木材，複合部材，高力ボルト，摩擦，支圧

1. はじめに

トルシア形高力ボルトを用いた鋼材と木材の接合部におけるせ ん断挙動に関する貴論文を大いに関心をもって拝読いたしました. 貴論文の要旨は, 接合部せん断実験, 経時変化評価実験, 3 点曲げ 実験により高力ボルトで締め付けた木材と鋼材のせん断剛性とせん 断耐力を調べ，それに基づいて複合部材の曲げ剛性および曲げ座屈 耐力を解析的に求め，当該複合部材の実用性を主張されたものと理 解します．接合部のせん断抵抗の考え方，せん断耐力の評価式，含 水率の影響等に疑問を感じましたので, 討論させていただきたいと 思います。

\section{2. 接合部のせん断抵抗について}

貴論文の論考は，論文題目からも伺えるように，高力ボルトで締 め付けた木材と鋼材の接合部に生じるせん断抵抗の源泉が摩擦に拠 るものであるとの前提に立っています。しかし, 討論者は摩擦抵抗 ではなく主として支圧抵抗に拠るものであると考えます。その根拠 は次の 3 つです，第 1 に，接合部せん断実験の結果（貴論文表 1)
から計算される $Q_{\mathrm{d}} / T_{1}$ が非常に大きな值（最大で 0.83）を示すもの があると言うことです.黒皮付きの鋼板の表面は滑らかであるので, 木材との摩擦係数がそのような大きな值となることは既往の摩擦実 験では報告されていませんし，高圧下における木材と鋼材の静摩擦 係数は鋼材表面の粗さに関わらず 0.3 程度であることが分かってい ます 1 . 寸すると, 荷重降下点 $Q_{\mathrm{d}}$ の手前で摩擦が切れて瞬間的な滑り が生じるはずですが，貴論文図 7 の荷重一ずれ曲線を拝見すると， そのような形跡は全く認められません，第 2 に，接合部せん断実験 で経時変化を調べた実験結果（貴論文表 2 , 表 3 および図 14）にお いて, 高力ボルトの張力が日数とともに低下してもせん断剛性にさ ほど変化が見られないことです．同様のことが，3 点曲げ実験にお ける経時曲げ岡性の変化がほとんどないこと（貴論文表 4）にも現 れています。このことからすると，接触面がせん断力によって剛体 的な滑りを起こすのではなく，木材のせん断変形あるいは荷重方向 への支圧変形が緩やかに進行し，座金の側面が木材に接触して支圧 状態になっていくと推測されます。その過程がせん断剛性として検 出されるのではないでしょうか. 第 3 に, 接合部せん断実験で得ら れた荷重一ずれ曲線（貴論文図 7）を拝見すると, 荷重降下点から

\footnotetext{
* 東京大学大学院工学系研究科建築学専攻 教授 $\cdot$ Ph. D.

Prof., Dept. of Architecture, School of Engineering, The University of Tokyo, Ph. D.
} 
急激な荷重低下を示しているものが多数ありますが, 降下後の荷重 レベルがかなり低くなっています。通常の摩擦接合の滑り試験では 滑った後の荷重はそれほど低下しませんし, 再上昇する曲線を描き ます，すなわち，この荷重降下は摩擦が切れて滑ったことに拠るも のではなく,木材が破壞したことに拠るものと推測されます.実際, 貴論文にもあるように, 接合部せん断試験体のボルト締め付け時に 木材が割裂したものがあることが破壊の可能性を示唆しています.

以上のことから，この接合のメカニズムは摩擦接合ではなく, 支 圧接合と考えられます，そうすると，この接合部に高力ボルトを用 いる意味は乏しく，普通ボルトで十分であるということになるので はないでしょうか．強力な締め付け力で座金の下にある木材を締め 固めても，木材の損傷を引き起こすだけで，せん断抵抗には寄与し ないのではないでしょうか. しかし，別の見方をすれば，木材の応 力緩和現象は非常に顕著であるので, 初期導入張力は時間とともに 減少し, 最終的にはゼロになってしまう可能性もあるわけで, その ことを貴論文で案じておられますが, 支圧接合であれば, 導入張力 を喪失しても問題ないと言えるのではないでしょうか.

\section{3. トルシア形高カボルトのエ法上の問題について}

貴論文では高力ボルトがトルシア形であることを強調されていま す。これはピンテールの破断により所定の張力を安定して導入でき るからということですが, 木材との接合では構法上のみならず工法 上も, 意味をなさないように思います. 構法上の問題は上で述べた ように, 応力緩和が起きるため初期導入張力が失われるからです. 工法上の問題は, トルシア形高力ボルトは頭が丸いため, 一旦ピン テールが切れてしまうと, 増し締めすることもボルトを外すことも できなくなります，なぜなら，供回りが起きるからです．普通の六 角ボルトによる接合方法 2)であれば，頭をスパナで拘束することに よって供回りを防止できます．討論者は，木材と鋼材の接合部にト ルシア形高力ボルトを用いる必然性を理解しかねます.

\section{4. せん断耐力の評価方法について}

高力ボルトで締め付けた木材と鋼板の最大せん断耐力に関する貴 論文の評価式をそのまま転記すると次式となります。

$$
\begin{array}{ll}
F_{1}=\left(F_{t}+F_{c}+2 F_{s}\right)(a-s b) R & \text { 原著(2) } \\
F_{2}=F_{t}(a-s b) R+2 F_{s}(a-s b)(L+R / 2)+F_{s} R(L-R / 2) & \text { 原著(3) }
\end{array}
$$

この評価式には次の疑問が生じます. 第 1 に, 式中の圧縮, 引張, せん断強さ $\left(F_{\mathrm{c}}, F_{\mathrm{t}}, F_{\mathrm{s}}\right)$ に, 国土交通省告示にある数值, 寸なわち $F_{\mathrm{c}}=18.0 \mathrm{MPa}, F_{\mathrm{t}}=10.8 \mathrm{MPa}, F_{\mathrm{s}}=1.8 \mathrm{MPa}$ を採用していることです. この数值は種々の安全率を含んだ低い值に設定されたものであるの で, 実験データの検証に用いるのは不適切です。すなわち, 貴論文 図 11 で評価式が実験值を概䄈予測できているという主張は無理が あると思います。試験体に用いたスギ製材から試験片を採取して, 当該木材の強さを直接調べた結果を用いるのが常道かと思います. 仮に, 平均的なスギの強さを木材工業ハンドブック 3)から引用寸る と, $F_{\mathrm{c}}=27.5 \mathrm{MPa}, F_{\mathrm{t}}=54.9 \mathrm{MPa}, F_{\mathrm{s}}=7.4 \mathrm{MPa}$ であり, 告示の值より ずっと高い值となります。これを貴論文の評価式に代入して実験值 と比較すると全く合わなくなります. 寸なわち, 図 10 の破断モデ ルは実情を反映していないのではなかろうかという疑義が生じます. 試験体の破壊状況が貴論文写真 1 から読み取れないのでモデルがど
うあるべきか正確にコメントしかねますが，少なくとも，引張強さ $F_{\mathrm{t}}$ は寄与しないと言えると思います。 なぜなら，木材が䋊維方向に 引張破壊する部分はどこにも存在しないからです.

評価式の第 2 の疑問は，摩擦力が含まれていないことです，木材 の応力緩和によってボルト張力が減少するとは言え, せん断実験の 際には初期導入張力の半分くらいが維持されています (貴論文表 1) したがって, せん断耐力に摩擦抵抗が加算されるべきではないでし ょうか. 仮に摩擦係数を 0.3 とすると, せん断耐力に占める摩擦抵 抗の割合は無視できないほど大きな值となります。

\section{5. 含水率について}

木材はクリープや応力緩和を起こす粘弾性体であることが知られ ています，さらに，厄介なことに，水分がその粘弾性挙動に大きな 影響を及ぼし, これはメカノソープティブ効果と呼ばれています. このことは比較的短時間で行われる静的試験にも現れ，静的な強度 や弹性係数が含水率の影響を受けます。 よって, 木材の力学的性質 を調べる際には含水率の值に注意を払って試験が行われています. 貴論文の接合部せん断実験（貴論文表 1）では木材の含水率が繊維 飽和点（約 $30 \%$ ）近辺の湿った状態で寸. 経時変化評価実験（同表 2，3）では数值がありませんが（貴論文に関連する大会梗概 ${ }^{4}$ ) では 40\%を超える值となっています)， 3 点曲げ実験（同表 4）では $14 \%$ 前後の通常の気乾状態になっています.すなわち, 試験シリーズを 通して含水率が一定の範囲にコントロールされていません，したが って，接合部せん断試験で得られたせん断剛性を使って 3 点曲げ梁 の曲げ剛性を解析的に予測し，それを 3 点曲げ実験で得られた曲げ 剛性と比較するような，含水率が大幅に異なる木材の実験データに 基づく相互比較は木材の性質上無理があるのではないでしょうか.

以上について,ご回答いただければ幸いです。

\section{参考文献}

1) 桑村 仁: 鉄骨木質構造の発展に向けた木材の割裂に関する研究 (その 13. 木材と鋼材のトライボロジーおよび高圧摩擦実験の必要性），（その 14. 圧縮一 引抜き法による木材と鋼材の高圧摩擦実験），（その 15 . 高圧下で の木材と鋼材の不完全摩擦および摩擦係数），2010 年度日本建築学会関 東支部研究報告集 I, pp.397-408, 2011.3.

2) 桑村 仁: 切欠き木材梁の割裂応力度 - 鉄骨木質構造の研究 その 1 - , 日本建築学会構造系論文集, 第 619 号, pp.111-118, 2007.9.

3）森林総合研究所：木材工業ハンドブック（改訂 4 版），丸善，2004.3.

4) 高木次郎他：トルシア形高力ボルトで一体化した鋼木複合断面部材の開発, 日本建築学会大会学術講演梗概集 (北陸) C-1, pp.47-54, 2010.9.

（2011年 4 月 7 日原稿受理，2011年 6 月 7 日採用決定） 